University of Michigan Law School

University of Michigan Law School Scholarship Repository

Articles

Faculty Scholarship

2010

\title{
The Basic Law at 60 - Equality and Difference: A Proposal for the Guest List to the Birthday Party
}

Susanne Baer

University of Michigan Law School, suba@umich.edu

Available at: https://repository.law.umich.edu/articles/33

Follow this and additional works at: https://repository.law.umich.edu/articles

Part of the Civil Rights and Discrimination Commons, Comparative and Foreign Law Commons, Constitutional Law Commons, and the Law and Gender Commons

\section{Recommended Citation}

Baer, Susanne. "The Basic Law at 60 - Equality and Diffeernce: A Proposal for the Guest List to the Birthday Party." German L. J. 11 (2010): 67-87.

This Article is brought to you for free and open access by the Faculty Scholarship at University of Michigan Law School Scholarship Repository. It has been accepted for inclusion in Articles by an authorized administrator of University of Michigan Law School Scholarship Repository. For more information, please contact mlaw.repository@umich.edu. 


\title{
The Basic Law at 60 - Equality and Difference: A Proposal for the Guest List to the Birthday Party
}

\author{
By Susanne Baer
}

\section{A. Introduction}

This birthday gives rise to many considerations. Some reflect upon achievements - the German constitution, named "Basic Law", has proven to work although many did not believe in it when it was framed. Others emphasize desiderata. Sabine Berghahn commented at the 50th birthday that it has developed "far too slowly and [some] has even gone completely wrong." ${ }^{1}$ Jutta Limbach, former President of the Federal Constitutional Court, observed that constitutional history was "anything but regal, but very difficult and full of obstacles." ${ }^{2}$ Former Chancellor Willy Brandt famously called the constitution "a snail on thin ice." So what is missing when we analyze the Basic Law, and what should be finally added - as spirit, in interpretation, in clarifying words? I will try to point to achievements and show what might still be lacking. This is what studies in constitutionalism always do. To do justice to the occasion, I will also think about who we should invite to celebrate this birthday. More precisely, if we are to celebrate the 60th birthday of Article 3 of the Basic Law, which is the equality guarantee, and which has been amended since its birthday, I will encourage you to think about who should come to this party.

Article 3 of the Basic Law is the focus and the title of this essay is "equality and difference". Many will expect to hear something about gender issues. This probably has something to do with the fact that I am a member of both the Law School and the Centre for Gender Studies at Humboldt University, a rare combination in an academic world that draws neat

\footnotetext{
"Prof. Dr. Susanne Baer, LL.M. (Michigan) is Professor of Public Law and Gender Studies at the Law Faculty a Humboldt University of Berlin, William W. Cook Global Law Professor, University of Michigan, USA, and visiting faculty at CEU Budapest. She is the Director of the Law \& Society Institute Berlin, and of the GenderCompetenceCentre, which advises governments on equality issues. Her research areas are socio-cultural legal studies, gender studies, law against discrimination, comparative constitutional law, constitutionalism and governance. For more, see http://baer.rewi.hu-berlin.de/. Email: baer@rewi.hu-berlin.de. This is the slightly updated lecture delivered at Humboldt University Berlin in 2009, in the series celebrating the 60th birthday of the Basic Law.

${ }^{1}$ Sabine Berghahn, 50 Jahre Gleichberechtigungsgebot, in EINE LERNENDE DEMOKRATIE 315 (Max Kaase and Günther Schmidt eds., 1999).

${ }^{2}$ Id. at 319.
} 
boundaries. But more importantly, most societies are rather obsessed with gender difference as the key social difference. There is data that tells us that we, as members of cultural majorities, orient ourselves by using labels like "men" or "women" when we enter this room; that we focus on gender when we, adding to the long list of constitutional fathers, emphasize the existence of four mothers of the German constitution; that we do not think about a complex web of inequalities when we discuss equality of women and, today in Germany often even more explicitly, equality of men; and that we do not consider interdependent inequalities if we turn our often antiquated notions of femininity and masculinity into issues for analysis and debate. We live with the schema of sex-asdifference in our heads. Therefore, equality could be understood as a fundamental right to a chosen, not schematized sex, or against the unreasonable demands to be pressed into gender stereotypes.

Because of the obsession with sex-as-difference I will try to tell a slightly different story. I do this from a perspective of constitutional history because the Basic Law's history on the subject of "equality and difference" provides more than anecdotes and jurisprudence on sex equality. I also hope to expand our vision of equality because we are all more than women, men, transsexual, or intersexual. This is never all there is to say about a person and if reduced to only this the labels go too far, and may even amount to an injustice. Finally, I look farther than the history of the constitutional guarantee of sex equality because one problematic aspect of constitutional concepts is to always focus on one difference, as the small but ideologically significant "difference with consequences." ${ }^{3}$ This method disregards the web of privilege and disadvantage that shapes our lives, best analyzed from a multiplicity of perspectives such as sexism, heterosexism, classism, racism, regionalism, ableism, etc.

So much said, this contribution to a reflection on the constitution on its $60^{\text {th }}$ anniversary deals with equality and difference in four different ways. First, I am conscious of several inequalities, and it is important to consider which contexts call for recognition of which inequality, and which kind of regulation of it. Second, any analysis of the right to equality does not only invoke questions of constitutional law and theory but also always implies questions of a practical philosophy, a theory of justice. An interpretation of the Basic Law poses very specific problems when it calls upon a polity to ensure equality but respect difference. It is the dilemma of difference, when a constitutional state shall apply laws equally to all to ensure justice, because each and every invocation of a difference in law exactly normalizes that difference, that is, it perpetuates the problem in order to solve it. ${ }^{4}$ Third, the stories of equality and difference are not only interesting as narratives, which

\footnotetext{
${ }^{3}$ This paraphrases a feminist slogan that refers to the penis as a small difference with large consequences.

${ }^{4}$ This has been called the dilemma of difference, or the feminist dilemma, by U.S. scholars Drucilla Cornell, and Martha Minow. See Susanne Baer, Dilemmata im Recht und Gleichheit als Hierarchisierungsverbot - Der Abschied von Thelma und Louise, 28 KRIMINOLOGISCHES JOURNAL 242-260 (1996).
} 
form constitutional cultures, but they are also fascinating from the perspective of sociolegal studies. The history of Article 3 of the Basic Law is a case in point of how far social realities may be removed from what a constitution promises. In addition, it is a case that shows how even an explicit promise in a constitution can be excluded, marginalized, disregarded in the mainstream of constitutional law - a phenomenon that is not really part of the concept of constitutional law. In a sense, the history of equal rights is also a history of constitutional denial, a history of the difference between proclamation and activity, an instance of blatant performative self-contradiction. Fourth, the question of equality and difference may also be asked from a comparative perspective. Can we distinguish what happened in Germany from what happened elsewhere, or are things rather similar, at least in Western constitutional states, capitalist countries, or Europe as a whole? Where do we stand, with the German constitution nine years after the European Charter of Fundamental Rights was drafted in 2000, and eventually entered into force in 2009? Where does Germany stand in light of young dynamic constitutions on several continents, as well as in light of the constitutionalization of other areas of law, like international trade orders, and of new concepts of human rights? Here, one can wander very far, yet my contribution can only hint at what seems to be different, and what seems to be similar, from a comparative point of view.

This birthday essay does not cover all aspects in adequate breadth and depth. A contribution to the 60th birthday of the constitution that focuses on equality and difference must also be limited in other respects. I will tell stories of Article 3 of the Basic Law because it is the basic and, thus, central legal article of equality. With this, I neglect other rules that target equality and difference, like Article 6 section 5 of the Basic Law (illegitimate children are to be treated equal to those born in marriage), Article 12 of the Basic Law (military service obligations must be born equally), Article 33 (all Germans have the same civic rights and obligations, in particular regarding access to public office), and Article 38 (the guarantee of the right to vote which ensures political equality, which Article 28 carries to the states of the Federation). There are also constitutional rules that refer to equal living conditions and to equal distribution of funds between the federation and the states, as in Article 104b and Article 106 et sequitur of the Basic Law. These provisions establish a mandate for social justice and economic equilibrium in this federal system. Rather, I focus on what has been traditionally called the "social question", which, as I will argue, should be understood as the question of rights against discrimination.

\section{B. Article 3 Stories}

Who should we invite to celebrate the 60th birthday of Article 3 of the German constitution? This is far from easy to decide. I want to approach the guest list, and thus a vision of the celebrations itself, with two questions. First, who should come? Which players have shaped the equality clause, with which interests and what kind of visions? Thinking about a guest list for the birthday party enables us to consider the governance constellations that make constitutional history. It also allows us to consider the social 
structure behind constitutional agenda-setting, and to shed light on some blind spots in of the jurisprudence on Article 3. Second, what will the celebration be like? Will it be a very specific event, with a certain touch, or just another celebration? This enquiry may help us understand whether there are distinct features to the history of Article 3 or whether this is the general story that can be told about all fundamental rights.

\section{Actors, Interests, Visions}

There are already quite a few Article 3 stories. More precisely: there have been attempts to reveal the legal history of Article 3 section 2 of the German constitution with a focus on the constitution-making body, sometimes known as the "framers". These attempts demonstrate how the sentence on equal rights for men and women made it into the Basic Law in 1949 and how adding a second sentence to the section, in 1994, was achieved. These attempts, especially as regards the 1949 Parliamentarische Rat (Parliamentary Council or Constitutional Convention) focus on Elisabeth Selbert. We would certainly invite her, were she still alive. A small historical vignette may tell us quite a bit about many issues that are still at work today.

\section{Selbert - A Paradigmatic Case}

Dr. Elisabeth Selbert, a member of the Social Democratic Party of Germany, or SPD, was one of the four mothers of the Basic Law. The others were Friederike Nadig also for the SPD, Helene Wessel for the Zentrum (Mainstream Party), and Helene Weber for the CDU (Christian Democratic Union). ${ }^{5}$ Certainly, we would invite them too.

\section{a) Presence and Representation: How Many are Four?}

That only four women deliberated over the Basic Law in the Parliamentary Council does not come as a surprise to many since politics is widely regarded as a male, or at least maledominated, field. Indeed, many are very happy that these four women have found their way into the memorial, constitutional culture of the Federal Republic of Germany, and I am too. But the number - four - is remarkable for other reasons particularly when we look at demographics in 1949. At that time, there were far more women living in Germany than men - estimates are about 5 million more. In over 5000 women's committees, which had been founded following an initiative of the Allied Forces after the war, the intention was not limited to "potato policy," ${ }^{6}$ namely organizing care and providing basic living

\footnotetext{
${ }^{5}$ Weber did not vote oin favour of the Basic Law because it did not guarantee for a transparent budget of political parties and did not allow for plebiscites on th efederal level; she also later fought against the rebuilding of the Germany Armed Forces.

${ }^{6}$ These committees were later turned into members of the Demokratische Frauenbund in the East, and the Deutsche Frauenring in the West.
} 
conditions. Rather, the committees were arenas where women were politically active. The political parties, however, were not amused and quickly decided that such activity was incompatible with membership - those who were active in the committees were not to be part of party politics. Thus, even the political establishment turned itself against the Allies' initiative. The result was the striking underrepresentation of women and the striking overrepresentation of men in the politics of the young post-War Germany.

This return of politics as a "Männerbund", a male bonding institution, also shaped the discussions while drafting the Basic Law. Elisabeth Selbert only entered the scene of the Parliamentary Council because Kurt Schumacher persuaded politicians from Lower Saxony to send her, since the party branch she herself was a member of, Hesse, did not intend give her a mandate. That which we call a critical mass today, ${ }^{7}$ the number of "others" that allow individuals to make a difference as a group, was not achieved. Worse, it was actively prevented. Today, the gender ratios in Parliament have changed, yet are still far from the figures that would correspond to the gender mix of those resident in Germany. The current "gender balance" in the German federal and state parliaments even gave rise to praise from the United Nations. ${ }^{8}$ But given the demographic situation, the gendered character of political representation in 1949 was, and in the year of the Basic Law's $60^{\text {th }}$ anniversary, still is in a rather sad state.

\section{b) Equality Illusion and Desolidarization: Divide et impere?}

Besides Elisabeth Selbert there were just three other women in the Parliamentary Council, but they were rarely on her side. Was this an early zickenkrieg (a bitches war)? This derogatory term was not in use at the time and this was generally a period in which such sexism had little currency. Women were rebuilding the Republic. They received ration cards for construction work, to feed themselves and their families. The image of the Trümmerfrauen (women of the rubble) is not a picture of unpaid voluntary work, of typically female altruism as mainstream memory prefers to paint it. Men had been killed in the war, were still prisoners of war, and were often traumatized. The female colleagues of Selbert in the Parliamentary Council certainly believed in pay equity ${ }^{9}$ and equal representation in parliaments, from the local councils to the federal Bundestag, but they

\footnotetext{
${ }^{7}$ Usually, the critical mass is set at around $20 \%$. Change occurs when the number of newcomers is large enough to prevent a single stigma, and forces the establishment to differentiate between individuals.

8 In the reporting on implementation of CEDAW, Germany has received positive comments only regarding political representation, and fares rather badly regarding equal pay, segregation of the work force etc.

9 On the history see Ines Reich-Hilweg, Gleicher Lohn für gleiche Arbeit, Blätter für deutsche und internationale Politik 5/2009, at 88 .
} 
took it to be a fact and did not do anything to fight for it. ${ }^{10}$ As a result of the circumstances at that time, they believed that sex equality was a given, a fact that was both too obvious to disregard and too entrenched to ever be undermined. This was a strategic mistake, as history shows, and part of a strategy of divide et impere (dividing to win). Again and again, this strategy stigmatizes one woman a suffragette, another a women's rights activist, another a feminist, all isolated from one another as radicals, while the others are highlighted as nicer examples of a forever rare species.

\section{c) Rhetoric against Better Knowledge}

Moreover, then as well as in 1994, ritualized arguments were raised to reject demands that the equality clause be made a shield against discrimination. Such rituals are used today to reject a demand to clarify that the equality law also protects against discrimination relating to sexual identity, in a campaign run by the queer NGO, LSVD called " $3+$ ". Such rituals were used to ward off demands by Selbert, when her calls for explicit recognition were rejected with the phrase that "this is already included", and, therefore, nothing changed. Article 3 of the Basic Law, the argument went, is sufficient to protect everything that is important in the field. However, before the Basic Law the Weimar Constitution included a toothless principle clause referring to equal rights and obligations of women and men, and now the Basic Law's more substantial equality clause makes no reference to sexual identity or orientation. But, so it was said, one could not seriously be calling for more! Anyone who employs such arguments denies validity to a constitutional claim, renders it beyond legal rationality. Many constitutional lawyers have done so in the course of the last 60 years, and many of these lawyers even knew better. These people are not invited.

In the responses to Selbert we are able to see early versions of a specific equality rhetoric that operates against better knowledge. It is the illusion of equality that women fall for, which results in a lack of mobilization for equality claims and a serious problem for gender equality politics today. It opens space for the strategy of divide et impere. It creates a problem of marginalization. It is a problem of the model women being courted at the expense of all other women, the majority. Against this background, it is not easy to agree on the guest list for the birthday party for Article 3. Hildegard Hamm-Bruecher, a famous woman in West German politics, told a Berlin daily in an interview that she had noticed the domination attitudes displayed by men at the time but would consider feminism "Kinkerlitzchen" (petty stuff) nonetheless. ${ }^{11}$ What does this mean? She also stated that

\footnotetext{
${ }^{10}$ After 1945, the taboo around sexuality as well as the unwillingness to discuss the gendered nature of violence, there was no public recognition neither of mass prostitution of German women in front of Allied army housing, or of the mass rapes of women right after the war ended officially.

${ }^{11}$ Interview, Der TAgesspiegel, May 17, 2009, at A1.
} 
she did not engage in women's politics because all politics are women's politics. ${ }^{12}$ However, the stories of the birth of Article 3 teach us that this should be said rather clearly and quite often (that would be, by the way, "feminism"). Derogatory talk about women and gender politics may be quite rational for women themselves to avoid a stigma, but it remains highly problematic nonetheless.

\section{d) Is Equality "Left"?}

Elisabeth Selbert, however, was supported in her equality claims by three men: Ludwig Bergstraesser of the SPD, a professor in Greifswald; Max Reimann and Heinz Renner, both of the Communist Party. We would invite them, were they still alive. This part of my historical vignette, however, also raises the following question. Is gender equality an issue of the political left? This is not an outdated question, even if questions of equality are now discussed by everyone on all sides of the political spectrum and negotiated with rather different results in the end. Particularly in an election year, everyone is in favor of equality - but just what exactly does that mean?

The East German Constitution was proclaimed a week before the West German Constitution. That paen to "real, existing socialism" contained a sentence on equal rights for women and men. This sentence easily found a majority, but an addition to that basic principle had to be fought for. Having won the fight, the concrete protection stated that all regulations that were inconsistent with the equality principle were to be declared invalid. This may indicate that, from a historical perspective, at least those who were officially "left" had problems with equal rights, too.

Yet the reputation that equality is not for conservatives is related to another phenomenon: whoever really supports equality must also rethink marriage and family, as well as sexuality and reproductive rights. If, insofar as conservative "values" find their place in marriage and family where they are meant to save "clear", "proper" or "adequate", de facto authoritarian and patriarchal structures, then conservatives must have problems with equality. Moreover, whenever labor movements wanted to leave things as they were in the private sphere, and only change the sphere of production, not the sphere of reproduction, they had the same problem.

In the constitutional debates of 1948, the fathers (and at least three mothers) of the Basic Law saw this very clearly, and clearly stated what they did not want. The esteemed and well-educated Carlo Schmid argued that the rules of the Civil Code, which explicitly privileged men, had been created to protect women - and should, therefore, remain in force. Dr. Elisabeth Selbert disagreed. She argued that the entire legal system was meant to respect fundamental rights, including the right to equality, and that there is no private

12 Hildegard Hamm-Brücher, Interview, DeR TAGessPiegeL, May 17, 2009, at A1. 
sanctuary for sexism. But this was exactly what was needed to restore damaged masculinity after the war and fascism. The controversies around equality oscillate around issues of family and marriage because culture, nation, and or religion create marriage and family to be the nucleus of the self, one's own, as well as the stronghold of patriarchal domination and apparently intact masculinity. This masculinity was severely damaged - as Himmler stated in 1945, "a men's state had failed." On top of this, only fifty percent of the estimated five million women in Germany were married, and there was an extremely high divorce rate at the time. Thus, issues of marriage and family were central to any discussion of equality in gender relations and are still relevant today.

There are many questions of gender relations that were not spoken about, but what was discussed and will be discussed is the family. In 1949 there were controversies surrounding Article 6 of the Basic Law because with it the framers protected "marriage and family" in one sentence, thereby insulating a privilege for, as feminists critisized, the "husband's family". Just as in the Weimar Constitution and in Article 33 of the Basic Law today, Article 3 section 2 was meant to guarantee the same civic rights and responsibilities, not more. What an insult to all the women who lived, specifically at the time, without a husband, but often wit ${ }^{\text {ho }}$ children! It was not the family living in Germany at the time that was meant to be protected but a patriarchal ideal. Thus, it is no coincidence that the Christian Democratic member of the Bundestag, Franz-Josef Wuermeling, immediately established a "battle group" for the family and the child, and then worked towards a Federal Ministry for Family Affairs, founded in 1953, which he was the first to run. ${ }^{13}$ It is also no coincidence that it took until the 1970 s to convince the Federal Constitutional Court to understand that families are a "generational connection", and should be protected as such, even when there is no marriage present. Today, the challenge is the same, if often phrased differently. For example, in the beginning of the $21^{\text {st }}$ century, German politics focus first and foremost on the family, and equality disappears into its shadow, quickly reduced to "compatibility" of work and family life. In the 1994 constitutional reform debate after unification, there was, again and also ritualized, the argument not to fiddle with existing regulation and not to interfere with the private realm. In recent years, the issue was the freedom of fathers not to use the right to stay at home with small children, or the issue was phrased as "our values". This raises the question again and again: does equality really matter everywhere, including the private realm? And which political program actually promotes equality in all spheres of life, leaving no sanctuaries?

\section{e) The Early Form of the "Blog"}

Elisabeth Selbert was soundly defeated in her initial demand to inscribe equality into the

\footnotetext{
13 Wuermeling, after the war, lead Fides Romana, a Catholic laymen's organisation. His ideas about the family have been published in his book. See Franz-Josef WUermeling, FAMILIE - GABE UND AUfGABE (1963).
} 
Basic Law - the majority in the Parliamentary Council repeatedly voted against her. She was confronted with rather blatant sexism and was subjected to all the techniques of political marginalization. The conservative Helene Weber only started to do something for the equality claim when she observed that and saw how equal rights were not taken for granted at all by her colleagues. Selbert then travelled the country, and made sure that postcards were written to memorialize it. Is this an early form of communicative referendum, which would now rely on blogs and e-mails? That is certainly one aspect. But it is also one of many instances in which elites - and even very educated elites like those who participated in the Parliamentary Council or parliamentary majorities - were unwilling to translate the signs of the times into legal text and to enshrine equal rights for women in 1949.

\section{f) Perpetuated Injustice}

Majorities were, in 1949 and again in 1994, unwilling to consistently pursue the idea of minority protection in other respects. In 1949, protecting homosexuals from discrimination was, apparently, not considered at all, even though gay men and lesbian women were targets of the fascist ideology of genocide. In 1994 a simple majority, but not the required majority to amend the constitution, was ready to protect people from exclusion on the basis of "sexual orientation" with an amendment to Article 3 section 3 sentence 1. In relevant cases, the Federal Constitutional Court sometimes uses the general equality clause of Article 3 section 1 because sexuality discrimination looks rather similar to other recognized forms. ${ }^{14}$ Yet, again, there is a refusal to recognize discrimination when it comes to relationships, marriage, and family. Therefore, it could well be that some judges are not invited to the party.

\section{g) A Difference ... or Equality?}

Finally, Elisabeth Selbert conceptualized equality differently from the way many people conceive of equality today. Selbert explained in 1949 that Article 3 section 2 was really meant to provide for recognition of difference in equivalence. Yet she also spoke on the radio about a "synthesis of male and female characteristics." ${ }^{15}$ Did she imply symmetrical equality meaning equal treatment if anyone is comparable and unequal treatment when similarity is lacking? Did she also mean that one could be further discriminated against when there is enough inequality to consider it a difference? Here lies the challenge of the Aristotelian concept of equality that still keeps us busy today. ${ }^{16}$ Selbert was a child of her

\footnotetext{
14 See Susanne Baer, Equality: The Jurisprudence of the German Constitutional Court, 5 Columbia Journal of European Law 249-279 (1999).

${ }^{15}$ See Carmen Sitter, Die Rolle der Vier Frauen im Parlamentarischen Rat (1995) (providing more information on the positions of all four women framers).

${ }^{16}$ Catharine A. Mackinnon, Reflections on Sex Equality under Law, 100 YALE L.J. 1281 (1990-1991).
} 
time. Those who claim the same today, despite all the evidence we have gained about individuality and the complexity of social structures, and insist that the law must protect "otherness", would be quickly removed from the guest list for a birthday for Article 3. 


\section{Grand Trajectories - Even in 1994}

The history of Article 3 does not begin and does not end with Elisabeth Selbert. But the evidence may indicate the grand trajectories that shape the issue of equality.

In 1994 it was predominantly women, again the minority in parliament, who tried to move a constitutional assembly to improve Article 3 of the Basic Law. It was the time of the quarrel over the quota. More precisely, it was a time when the overwhelming majority of German professors of constitutional law and the majority of administrative courts who had to decide cases in which quota rules were applied to promote women in public service, considered affirmative action policies to be a violation of the equality principle. At the time state legislatures led the way. On the federal level, affirmative action for women "the quota" - was considered a tool non grata. So, what happened in the then formed Constitutional Assembly, consisting of member of parliament as well as representatives of state governments, formed by the Bundestag and the Bundesrat as a joint enterprise, which again addressed a radically changing social situation, because of the very high participation of women in the workforce in the GDR? Rupert Scholz, an esteemed professor of constitutional law, formerly German Minister of Defense and Member of the Bundestag, had the idea to confront a state representative at the time, judge and later Minister of Justice in Hamburg and Berlin, Lore-Marie Peschel-Gutzeit, with the argument that it is an unconstitutional idea to inscribe a guarantee of real equality into the constitution. Here, we see a repetition of the ritual of "it is already there - and you cannot seriously ask for more." Since elections were coming up, it has been said that Chancellor Helmut Kohl intervened and Rupert Scholz yielded. Would you invite them?

In the debates of 1994, every word was taken apart, and finally, a second sentence was hard won as a supplement to Article 3 section 2 . It reads: "[t]he state shall promote the actual implementation of equal rights for women and men and work towards the elimination of existing disadvantages." There was much less resistance to an amendment to section 3, which added a second sentence: "[n]o one shall be discriminated against because of his disability."

Despite tens of thousands of petitions to the Assembly to also protect people of different sexual orientation against discrimination, there was no required two-thirds majority for this claim. It was, from a perspective of electoral strategy, obviously not interesting enough to cater to these people. It also shows that there was no public recognition, in 1949 or 1994, of the injustice homosexuals suffered under the Nazis, discrimination that lived on in the form of a criminal law against male homosexuality after 1945 and still lingers when we observe that there is still no consensus that all forms of homophobia are violations of the law. Also, there are the ritualized arguments, deployed against Selbert when demanding women's rights in 1949. What is already written in the constitution is sufficient, so they say again and again, or it is unconstitutional to ask for more since more protection endangers the protection of marriage and family, itself protected in traditional 
terms in Article 6. In 1949 some would have referred to minorities as "sick people" whereas today we discuss "lifestyles". But in both instances the constitutional issue is the protection of minorities against discrimination, and also a protection against changing political whims of majorities.

\section{Constitutional History from Below}

The history of Article 3 is not only a history of ritualized arguments, but has always also been a history of constitutional law from below. When Elisabeth Selbert found she had no parliamentary majority behind her she travelled the country, called meetings, and wrote postcards. In 1994 this issue was taken up again by women's bureaus. In the birth year of the Basic Law Theodor Heuss, the first President of the new Federal Republic, said, given the laundry baskets filled with postcard petitions relating to Article 3 section 2 of the Basic Law, that it looks like a "tiny quasi-turbulency" to then conceal that his party, the liberal FDP, had turned against Selbert's proposal for Article 3, and now claimed that it had always been equal rights they wanted. Again, this is a ritual. Heuss would not have necessarily been invited to the party, but we assume that his wife, the feminist Elly Heuss-Knapp, would have brought him along. But, if we consider constitutional history from below, we need to think about civil society first and then about government representatives who are not necessarily hegemonic forces, then about claimants, lawyers, and judges, who may or may not go against the tide, and finally about legal scholars, a distinct actor in the German setting.

\section{Civil Society}

If Article 3 were given a birthday party we would need to invite quite a few who are not part of the official canon of legal history. There are the citizens who wrote the postcards, letters, and, later, e-mails, made speeches, and discussed the issue. There are the civil rights organizations that used judicial procedures to improve the constitution from below. There are NGOs that are trying to address a lack of equality, from outside, without parliamentary majorities. Today, just as one example, there is an initiative which calls for women on boards of directors - a claim for equal opportunities that has been rejected by the Bundestag when the bill was introduced by the Green Party. ${ }^{17}$

\section{Women in Ministerial Positions}

Along with civil society, the stories on Article 3 cannot be told without women in ministerial positions, and those who supported them in these ministries. Interestingly,

\footnotetext{
17 Parliamentary proposal of the Green Party „Quote für Aufsichtsratsgremien börsennotierter Unternehmen einführen“, Bundestags-Drucksache. 16/5279 v. 9.5.2007; and Drucksache 16/12108 v . 4.3.2009; with a hearing of the Committee of Legal Matters, 7. Mai 2008, and the protocol at http://www.bundestag.de/ausschuesse/a06/anhoerungen/archiv/35_quote/05_wortprotokoll.pdf.
} 
there were quite a few career-changers, entering from the sidelines, who qualify for our guest list. Those Quereinsteigerinnen (those who cross professional boundaries) in politics have often actively worked towards getting gender equality issues on the agenda, and often moved way beyond departmental responsibility. My invitation list to the birthday party would thus include the names of Jutta Limbach, as Minister of Justice in Berlin, later President of the Federal Constitutional Court, and the already mentioned Lore-Marie Peschel-Gutzeit, or Karin Schubert, both of whom also served as Ministers of Justice at the state level. In addition, there is also Hans-Jochen Vogel, ${ }^{18}$ at times a Minister on the federal level, and later a mayor of Berlin, who would be invited in light of his contributions as an expert in the constitutional deliberations in $1994 .{ }^{19}$ And one should consider, albeit somewhat reluctantly, Ernst Benda, also once a president of the Federal Constitutional Court, who defended affirmative action for women in state laws, yet also opposed a proposal to tie the economy in some way to gender equality requirements. ${ }^{20}$

\section{Plaintiffs, Lawyers, and Courts}

Minorities that fail to win a majority of enlightened political office-holders - women, homosexuals, the other others, to name minorities in light of power, not just numbers - in questions of fundamental rights, must go to court. It is particularly the histories of equality law that have not been written by policies and parliaments, but have been shaped by courts. Therefore, there are a few judges on our guest list for birthday party. But before we invite them, as people educated in socio-legal studies, we need to think of some others first.

More precisely, the history of the recognition of fundamental rights to equality of all human beings is, in German constitutional law, a history of mobilizing Article 3 as a fundamental right against the legislative majority. It is the story of people who opted for a constitutional complaint, and a story of lawyers and civil rights organizations or trade unions who supported them. However, regarding the trade unions, we must carefully differentiate. In the early days of Article 3 it did not prevent the parties of collective labor agreements, including the trade unions, to first establish "women's wages" and then call them Leichtlohngruppen (light wage groups), to legitimize unequal pay and, thus, pay women badly. Again, this indicates that equality is not necessarily a matter of the "left". Today, the unions have joined the call for pay equity, although we are still far from really asserting that. So, should anyone from the other side, the employers, be invited? Regarding this segment of society, it probably still looks a bit worse than among

\footnotetext{
18 FrauenRechte im Grundgesetz des geeinten Deutschland 159 (Jutta Limbach and Marion Eckertz-Höfer eds., 1993).

19 Id., at 98 et seq.

${ }^{20}$ ld. at 86 (quoting of Justice Ernst Benda).
} 
professors, but there are some entrepreneurs and managers who live equality the entrepreneurial way, and we will certainly invite them.

Thus, legal history is written by many, and especially by those who lodge complaints. Sociology of law allows us to open our eyes, based on research on the mobilization of law, to see and recognize not only the institutions which render judgments, but also those who move them there. Then, it also becomes apparent who actually moves the law and eventually creates landmark decisions based on what kind of concern and with which goals. In gender equality law it is very often men who complain about too much equality, and sometimes companies which, for example, want to see women work nightshifts. Would you invite these litigants?

The life story of a fundamental right is, therefore, also the story of many trips to Karlsruhe, the site of the Federal Constitutional Court and the Federal Court of Justice, or to Kassel (now Erfurt), the location of the Federal Labor Court, or to Berlin (now Leipzig), to the Federal Administrative Court. I only focus on the Constitutional Court. The history of Article 3 of the Basic Law before this Court is also quite amazing. It is not a history of the difference between the sections of Article 3, and between the inequalities that Article 3 section 3 mentions. The general principle of equality in section 1 was used to move the legislature towards more rationality, and, today, it is the location of a proportionality test. That is a success story, and congratulations must be extended for this "new formula" and that proportionality test that turned a general justice consideration into a structured analysis.

Then, the specific principles of equality enshrined in sections 2 and 3 are almost wholly dormant. However, there is a rather shocking decision from 1957 on homosexuality, in which the Federal Constitutional Court pathologizes men and women regarding their innate levels of aggression and passivity and stigmatizes what falls beyond the heterosexual frame. ${ }^{21}$ The Court even argued that the fact that the law in question originated from the Nazis was no reason to change it. ${ }^{22}$ So there is once again the question: why this blindness, the cruel disregard of those experiences?

There is no Article 3 decision on anti-Semitism, even though the Court had to deal with anti-Semitic statements and actions several times. In none of these cases did did the Court mobilize the explicit prohibition of discrimination in Article 3 section 3 sentence 1 . Why this blindness?

Regarding racism, we observe the same. The Court held in 2007, in a decision on East German land reform, that a special compensation for those who had been subject to racist

\footnotetext{
${ }^{21}$ BVerfGE 6, 389.

22 Id. at para. 109 and 121.
} 
persecution was constitutionally valid ${ }^{23}$ but does not mention, as in other decisions, Article 3 section $3 .^{24}$ The exception is probably the decision on police dragnet investigations issued in 2006. There, the Court stressed that, when the police use characteristics that are mentioned in Article 3, searches may amount to a special dimension of stigmatization, and, thus, may constitute a violation of fundamental rights. ${ }^{25}$ It can be read as a decision on racial (in fact: racist) profiling. Whoever came up with this argument should be invited to the birthday, but the others?

In light of this jurisprudence one may ask whether this difference of inequalities is simply a hierarchization of them, in which some are important and others not. It seems as if there is a sword of Damocles hanging here, as if sad history fogs the view, as if the Court was hesitant to accuse the legislature of acting, ultimately, like the Nazis. It is interesting to note that the accusation of gender discrimination does not seem to weigh as heavily. The gender issue is not a dormant one in Karlsruhe. Rather, we observe quite the opposite. It does not always come easily to the Court but it has by now declared that the legislature disadvantages women or men rather often. Over time, there were more than 100 decisions on the subject. So is sexism not that bad, and the Court is, therefore, more willing to be outspoken here?

The differences in dealing with inequalities become even clearer in court decisions regarding transsexuals. Of all the decisions on equality and gender, some significant rulings deal with transsexuals. There we may properly celebrate a birthday because all claims of transsexuals were successful. Here, the Court sees the coercion of gender roles much more clearly than usual. However, the Court detours around equality by referring to a right to self-determination, to protect transsexuals from discrimination. To do otherwise would have required the Court to open up marriage for homosexuals. But we may celebrate this nonetheless.

When it comes to women and men the Court is rather ambivalent. In 1953 it emphasized, in the first decision on gender issues, that Article 3 is a true fundamental right. The Court complained that the constitution is not only misinterpreted or violated in exceptional cases but that it is ignored - a tragic accident in the history of the Basic Law. For many years the

${ }^{23}$ BVerfG, 2 BvR 2462/07 from Dec. 15, 2008, at para. 11, available at
http://www.bverfg.de/en/decisions/rk20081215_2bvr246207.html.

24 See, e.g., BVerfG, 1 BVR 2793/04 from Dec. 19, 2007, available at http://www.bundesverfassungsgericht.de/entscheidungen/rk20071219_1bvr279304.html (racist slogans at a rally); BVerfG, 2 BvR 486/05 from March 8, 2006, available at http://www.bundesverfassungsgericht.de/entscheidungen/rk20060308_2bvr048605.html (military judgments violate Art. $3 \sec 3 \mathrm{BL}$, with emphasis on dignity).

25 BVerfG, 1 BvR 518/02 from April 4, 2006, at para. 111, available at http://www.bundesverfassungsgericht.de/entscheidungen/rs20060404_1bvr051802.html. 
Court also treated the explicit guarantee of gender equality in section 2, which was so hard-won in 1949, as a drafting error. ${ }^{26}$ When it comes to discrimination, the court still prefers to look at section 3 only. There is ambivalence.

This blindness regarding Article 3 section 2 also has consequences in that it individualizes social issues. With this tiny shift in focus gender justice is negotiated as a question of gender difference in the symmetrical comparison between women and men. In the first half of the life of Article 3, in line with the restoration of the German economic miracle, the Court set out to rebuild the country in terms of gender roles, and emphasized the naturalbiological gender differences and the ensuing "functional division of labor." ${ }^{27}$ There are many impressive formulae that evoke the duties of the housewife. It was only in the late 1970s that the Court started to say that "it is not a part of the gender characteristics of the woman to perform housework." ${ }^{28}$ Today, open sexism has largely disappeared from the Court's decisions. What has not disappeared is the ideological concept of marriage and family, especially in tax and social security law, which still results in discrimination. Also, what has not disappeared is the dive into the Zeitgeist. A case in point is, today, the emphasis on fathers' rights, without the willingness to also insist on the duties that really correspond with parenting. Does the Court, thus, mainly follow the tide of the times, failing to secure rights against even elected majorities?

However, the interpretation of Article 3 only moved away from simple biologism in the 1980 s and 1990s, as mainstream beliefs on this subject shifted in society. There were important decisions of the Federal Constitutional Court from 1987, on retirement age, and from 1992, on nightshifts. How did that happen? Who was behind it? Individual judges and some clerks at the Court were not without influence. The litigants argued just as well as many organizations that were asked to comment on the issue at hand. But we should also remember that the European Court of Justice (ECJ) also often went ahead. The ECJ, over the course of time, and often in cases that came from Germany, had to discuss quota regulations, and clarified several controversial aspects. The German Federal Constitutional Court never decided the issue, but the ECJ clarified that equality means no one shall enjoy an automatic preference; no one shall profit from the use of seemingly neutral criteria which, in fact, privilege men; and that things must be done to ensure that more women finally have a career. Thus, the Federal Constitutional Court had to lecture German parliamentary majorities and sometimes force them towards equality, but it was not the one who spearheaded the fight. Rather, it was swimming in the stream of time, now with the rest of Europe.

\footnotetext{
${ }^{26}$ BVerfGE 39, 169 (185) (overruled by BVerfGE 74, 163 (179)).

${ }^{27}$ The list is long, and starts with BVerfGE 3,225 and BVerfGE 5, 9.

${ }^{28}$ BVerfGE 52, 376 .
} 
The somewhat reluctant stance of the Court, a stance based on the idea of no dissent from social convictions to ensure equality, was not only evident in matters of family and marriage but also in decisions on abortion. In 1974 the judges did not even think about the fact that abortion actually has something to do with gender relations, but pondered instead - over seven pages of the text - the mother's body and her willingness to sacrifice. In 1993, in the oral hearing on the case that would become the Court's second abortion lodestar, the Court's justices asked such sexist questions that, at one point, the Brandenburg government representative, Regine Hildebrandt, angrily wondered aloud about what was "really going on here." She would definitely be invited, were she still alive. What she had heard in the proceedings was, as she might have put it, "old patriarchal candy". But in its decision, the Court imposed on women a "fundamental legal obligation to carry the child to term," ${ }^{29}$ and denied them the moral authority to decide for themselves without compulsory counseling. Rather, "the willingness to protect" must be, as the Court saw it, "awakened." The word equality does not appear once in the judgment, and Article 3 section 2 is only referred to when the Court states that women indeed are allowed to work and be employed. Does the Court, in these cases, master the task of securing equality in difference and equal rights against discrimination?

\section{Legal Scholarship}

In addition to the claimants, associations, NGOs, and courts, there are also stories of Article 3 that are written by legal scholars. In Germany the legal academy is a rather influential player in the history of law. ${ }^{30}$ From the perspective of those who consider equality to be important, however, there are also some rather inglorious developments. Many German constitutional law professors would not be invited to the party, not even today.

In the early days, Richard Thoma, already a very prominent constitutional lawyer in Weimar and co-editor of the influential "Handbook of German State Law," delivered an expert opinion in which he argued that "we need to treat equal things equally and unequals unequally" - a condensed version of Aristotle's reflections on equality, which prominent Nazi-lawyers like Scheuner used to justify the Holocaust. Thoma certainly did not intend that but he also did not succeed. In the 1980s and 1990s there were many constitutional law articles arguing against affirmative action legislation to support women in the civil service of the federal states. This was very similar to the flood of publications around the year 2000, when many scholars considered the civil partnership law for homosexuals to be clearly unconstitutional. Would you invite these commentators? What do you think about extending birthday party invitations to people who are meant to

\footnotetext{
29 BVerfGE 88, 203, heading 3.

${ }^{30}$ Susanne Baer, A Different Approach to Jurisprudence? Feminisms in German Legal Science, Legal Cultures, and the Ambivalence of Law, 32 CARDOZO WOMEN's LAW JOURNAL 251-285 (1996).
} 
systematize and enlighten jurisprudence, not least in recognition of human rights, who fail to do so because of prejudice?

In any case, there are still too many who quarrel with Article 3 today. Justice Udo Di Fabio, a prominent voice on the Federal Constitutional Court, wrote in 1997 that gender equality is a "Fremdkörper (foreign body) in the system of fundamental rights." "31 This is, in matters of equality rights, rather a problematic term. But, Justice Di Fabio is also not alone. I would invite him, perhaps, so that many people can have a serious word with him. A pity that such dialogue does not always help. For example, during constitutional reform deliberations in 1994, some colleagues argued that it would be totalitarianism to call for equal rights, and some stigmatized women as always and only 'mother', and the like. ${ }^{32}$ So, will we have almost no legal scholars at the party?

German scholarship of public law is characterized by an extreme over-representation of men. In addition, and similar to the situation we observed in the Parliamentary Council, there are quite a few women in the profession who would never say anything about equality so they would never be considered feminists or, worse, homosexuals. However, beyond these, there are a few individuals who deserve an invitation. One such exception seems to be Karl Heinrich Friauf, a law professor in Cologne, who started as early as 1981 to address measures towards the advancement of women in employment. Likewise, the Frankfurt law professor Erhard Denninger and his colleague Spiros Simitis have clearly worked towards equality, especially given Simitis' attempts to educate the profession with strong words about patriarchal German family law. I am a bit biased when it comes to these two because they were my mentors and advisors on my dissertation, but I am sure I could convince anyone to invite them based on the facts. In addition, there is Edzard Schmidt-Jortzig from Kiel, eventually federal Minister of Justice, who deserves an invitation because of his arguments in the constitutional deliberations on Article 3 in 1994.

Then, there are the women, and it is clear that it is not all female scholars who may automatically dance at the party. In fact, there is Ute Gerhard at the University of Frankfurt am Main ${ }^{33}$ as well as, now in Basel, Andrea Maihofer. ${ }^{34}$ Both are not in legal studies, but worked on legal history, philosophy and gender studies in sociology, and, thus, intruded from outside. Then there is Vera Slupik, with her rather creative dissertation on the equality clause in $1988,{ }^{35}$ and Ute Sacksofsky, now a law professor in Frankfurt am

\footnotetext{
${ }^{31}$ Udo di Fabio, Die Gleichberechtigung von Mann und Frau, 122 ARCHIV DES ÖFFENTLICHEN RECHTS 404, 406 (1997).

32 Supra note 15 , at 102 (statement by Schmitt Glaeser).

33 Ute Gerhard, Gleichieit ohne Angleichung. Frauen im Recht (1990).

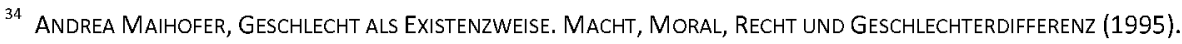

35 Vera SluPik, DIE ENTSCHEIdUNG DES GRUNDGESETZES Für DIE PARITÄT IM GESCHLECHTERVERHÄLTNIS (1998).
} 
Main, with her seminal book on the fundamental right to equality first published in 1991 and updated in $1996 .{ }^{36}$ She has moved things and has been criticized much more harshly than many others, sometimes even unfairly attacked. In addition, we would invite Sibylle Raasch, at the University of Hamburg, as well as Heide Pfarr, another Hamburg professor, in government roles at times, and then head of the German trade union's research institute. Certainly, this list would need additions. So, in the end, it will definitely be a party.

\section{A Special Case?}

Finally, one wonders whether this will be a special celebration. Are there features of the equality clause of Article 3 that differ from those we find in the history of other fundamental rights?

Article 3 section 2 is probably the only fundamental right that made it into the constitutional text based on the type of grass-roots pressure that I have described. ${ }^{37}$ In some ways, it is the illegitimate child which, 60 years ago, was brought along by her single mother, and who the fathers of the Constitution only accepted with difficulty. This is illustrated in the constitution itself, since Article 117 of the Basic Law clarified that the Parliamentary Council was forced to accept the gender equality phrase, but was not willing to change all laws accordingly. Rather, Article 117 included a generous deadline of 1953 to implement that part of the constitution. The legislature let that deadline pass, which is why the Court, in its first decision, had to say that the constitution is really a binding constitution that cannot abide a deliberate breach. It is said that, then-Chancellor Konrad Adenauer even tried to have the deadline extended. So, until something really happened, in the case of the specific right of equality, it always took a lot of effort to mobilize assemblies, the Constitutional Court, the ECJ, and the actors I mentioned above.

Article 3 is thus a fundamental right that was not intended to really be one. Again, this is why the Constitutional Court emphasized in 1953, the deadline year, that the clause is a "genuine legal norm." It had to tell parliament that the Parliamentary Council had really said what it said? A rather impressive operation. In 1957, 4 years overdue, the parliament passed an "adaptation law" but it carefully preserved the primacy of family responsibilities in relation to employment opportunities for women until 1977. It was only in 1977 that the disintegration of a marriage became sufficient reason to obtain a divorce. The family ... ever the nucleus of a special constitutional state.

\footnotetext{
36 Ute Sacksofsky, Das Grundrecht auf Gleichberechtigung. EIne ReChtsdogmatische UnTersuchung ZU ARTIKEL 3 ABSATZ 2 des GRUNDGESETZES (2 ${ }^{\text {nd }}$ ed. 1996).

37 Antje Späth, Vielfältige Forderungen nach Gleichberechtigung und „nur" ein Ergebnis: Artikel 3 Absatz 2 GG, in FraUeN IN DER GESCHICHTE 122-167 (Anna-Elisabeth Freier and Annette Kuhn eds., 1994).
} 
Is Article 3 a more controversial right than others? Not necessarily. Freedom of expression and data privacy are also good candidates for controversy, and it seems that freedom of religion, reminding us of the beginnings of constitutionalism, will be a focal point of disagreement today. But Article 3 , the equality right, is a fundamental right that is raised in any conflict and everyone is always already implied as a potential party to a conflict, or at least feels that way. In addition, most people feel like ad hoc experts when it comes to gender issues because they - or we - all have very influential schemata in the back of our minds. Moreover, there are the forceful taboos around sexuality, around the body, and around the religious conceptions of gender that inform such controversies. It is thus the proximity to the personal and the illusion of expertise that give equality conflicts a specific flavor. It is striking that Article 3 is a fundamental right that has often not been activated although it was obviously implied. This also makes this issue a little bit special. We have a very peculiar birthday to celebrate, and will, thus, have a very special party.

\section{Birthday Wishes}

Some stories have been told. We have an idea of who would be invited. So what else needs to be done? The after-dinner speech.

On the occasion of the 60th birthday, I wish three things for Article 3: a bit of historical reflection, self-critical at best; a keen sense of comparative constitutional attention; and the opening of law towards knowledge that is available to us to more fully understand inequalities.

Reflection upon the histories of the Basic Law may teach us a lesson about the importance of equal rights so minorities are not left at the mercy of majorities. Therefore, it is appropriate to support the aforementioned initiative, Article $3+$, to explicitly guarantee constitutional protection to people of different sexual identities. It is said that just such an attempt driven by some German states failed to gain approval in the second chamber of the Bundesrat in 2009. In addition, it would be a good idea to seriously consider the problem of age discrimination. Age is not yet mentioned in Article 3 but age discrimination is one of the big demographic challenges we face. Finally, the Basic Law should maybe say goodbye to the term "race" in Article 3, and, instead, take a stand against racism similar to the Constitution of South Africa. With this, we could learn from comparative constitutionalism. This may even be more inspiring when it comes to interpreting Article 3 of the Basic Law. Interpretation of the equality clause could and should be based on a European standard, as it is stated in Article 21 of the Charter of Fundamental Rights, which enters into force with the Treaty of Lisbon. In addition, there are numerous statements on constitutional and human rights that could enrich our understanding of equality and difference.

Finally, the stories about equality and difference in constitutional law also tell us that lively cultures of fundamental rights are not only dependent on doctrinal finesse; although we 
have to discuss whether self-determination trumps rights against discrimination and whether equality rights should be structured like liberty interests. Beyond that, it is also important to understand social contexts in order to respond to them appropriately through law. It is often civil rights organizations that bring additional and required knowledge to the table and it is also something provided for by interdisciplinary legal studies. The lecture series that generated the contributions to this special issue was, thus, organized by the German civil rights NGO Humanistische Union and by the interdisciplinary institute for research on law, the LSI Berlin. If we listen more carefully to these voices in the future we might contribute to an understanding of equality against inequalities and to achieve equality in light of our differences. The next birthday of Article 3 would then deserve a larger and more glittering celebration. So, who would you invite to celebrate the birthday of Article 3? What would you say in your after-dinner speech? 